\title{
Introduction
}

\section{Thomas Paine, America’s First Public Intellectual}

\author{
IAN SHAPIRO
}

Thomas Paine died in I809 at the age of seventy-two, by coincidence the year in which both Charles Darwin and Abraham Lincoln were born. Lincoln would turn out to be a great Paine admirer. ${ }^{1} \mathrm{He}$ was strongly influenced by Paine's rhetorical style and in I 835 even wrote a defense of Paine's deism, which a friend, Samuel Hill, destroyed before it could be published, out of concern for Lincoln's political future. ${ }^{2}$ Deism, the doctrine that humans can know that there is a creator who, like a watchmaker, set the world in motion but nothing further about him, was among the most incendiary of Paine's convictions - defended at length in The Age of Reason, published in two parts in 1794 and I795. The threat that it posed to organized religion attracted vitriolic opprobrium from many quarters, which he never managed to shed, despite his once-exalted status as the philosopher of the American Revolution, whose pamphlets and books had sold in the hundreds of thousands and been read by millions. The fact that Theodore Roosevelt would feel the need to dismiss Paine, incorrectly, as a "filthy little atheist" many decades after his - and Lincoln's - deaths suggests that Hill's action had been prudent. ${ }^{3}$ Darwin had no direct connection with Paine, but his discovery of natural selection led him to reject Christianity in favor of a similar kind of deism to Paine's - though Darwin would eventually become a fully fledged agnostic. Unlike Lincoln, Darwin did not need to be saved from himself by his friends. He generally remained circumspect about what he knew would be unpopular views. In I873, he cautioned his son George against publishing a diatribe against prayer and belief in the afterlife, to avoid "injuring your own power \& usefulness."

Paine would have been incapable of heeding-perhaps even of hearing-such advice. Whatever he was, Thomas Paine was not circumspect. Convinced that life is "a daring adventure, or nothing," ${ }^{5}$ he lived with astounding directness, optimism, and confidence-in himself, in others, and in his ideas. This is all the more remarkable in view of the many setbacks and failures he experienced throughout his life. He lost numerous jobs and all his assets several times. His first wife died in childbirth, and his second 
marriage ended following a humiliating business failure and personal bankruptcy. He suffered from severe illnesses-including typhoid, which almost killed him on his first transatlantic voyage in $\mathrm{I} 774$. He was betrayed by erstwhile friends and associates, with devastating consequences for his liberty and his reputation. He was convicted of seditious libel and burned in effigy for his attack on the British monarchy in his Rights of Man. Though he escaped to France, where he was named a French citizen and elected as a deputy to the National Convention, in 1793 he was imprisoned and narrowly escaped execution by the Jacobins for trying to save the life of Louis XVI. The American Federalists attacked him relentlessly for his defense of the French Revolution. He had to scrape together an ignoble living during his declining years. He was buried on his farm in New Rochelle, New York, with a mere six mourners in attendance, having been denied interment in a Quaker cemetery. Even in death Paine was shunned. William Cobbett, who had overcome earlier antipathy to become one of Paine's great devotees, exhumed his body in I8I9 for reburial in England. But permission was denied. His bones were subsequently lost; they have been the subject of macabre speculation ever since. ${ }^{6}$

Yet Paine bounced back from his many catastrophes, sometimes with astonishing panache. Indeed, inventiveness and resilience marked him from the beginning. He would never have amounted to anything more than a regional excise collector in Lewes, East Sussex, England, were it not for his audacious self-confidence leavened by a capacity for bootstrapping, which has seldom, if ever, been matched. For all practical purposes self-educated and lacking any advantages of birth, Paine would become a major figure in elite circles in Britain, France, and the United States and a confidant of three American presidents as well as Napoleon Bonaparte. His mother was the daughter of a relatively well-to-do lawyer, but she married down, with the result that Paine had to leave school at the age of twelve and apprentice in his father's trade of stay-making.

In 1756 the Seven Years War gave him his ticket out. Rejecting his father's counsel, he enlisted as a privateer and earned a thirty-pound commission. This small fortune enabled Paine to move to London and talk his way into the bustling world of intellectual clubs and cafés spawned by the new intelligentsia, where he came to know - among others-Benjamin Franklin. This would turn out to be a fortuitous connection. In late I774, following the death of his wife and child, his failed stay-making business and second marriage, and his dismissal from the excise service prompted by a quixotic attempt to get Parliament to improve conditions for tax collectors, Paine 
left for America at the age of thirty-seven. A letter of introduction from Franklin gave him his entrée into Philadelphia society. ${ }^{7}$

Even armed with Franklin's letter, which recommended Paine only for a modest teaching or clerical position, he faced an uphill battle in the New World. No one could have guessed then that this underachieving middleaged misfit was soon to become a household name; that Common Sense (I776) and his sixteen pamphlets on The Crisis $^{8}$ (I776-I783) would widely be heralded for galvanizing Americans to demand full independence and sustaining the Revolution's army through the worst days of the war, "when nothing but hope and virtue could survive"; 9 that his Rights of Man (I79I-I792) would become the definitive critical response to Edmund Burke's Reflections on the Revolution in France-provoking enough unrest throughout England to convince William Pitt's government to ban it, burn it, and declare war on its author; that The Age of Reason would be a blockbuster on both sides of the Atlantic, selling hundreds of thousands of copies and provoking dozens of responses-including from such leading theologians as Joseph Priestley and Richard Watson; or that his case for redistribution in Agrarian Justice ( 1797 ) would still be in currency more than two centuries after its publication. ${ }^{10}$ When the shivering, delirious Paine was carried off the deck of the London Packet in Philadelphia's harbor in December of 1774 , that all lay in the future.

Soon after Paine had recovered from the rigors of his transatlantic voyage, he persuaded one Robert Aitken, the owner of a bookstore and printing press, to start publishing The Pennsylvania Magazine under Paine's editorship. It was an overnight success, in a few months attracting fifteen hundred paid subscribers. This made it the most widely read periodical in the New World. ${ }^{11}$ Paine wrote much of the magazine himself under various pseudonyms, honing the skills that would soon make him the best-selling author of his generation. He fell out with Aitken, however, while trying to renegotiate the terms of his employment, reflecting a dynamic that would repeat itself throughout his life: Paine fought not only with his adversaries but also with allies and even friends. Combining unusually large doses of generosity, courage, and vanity, he frustrated his supporters, goaded his enemies, and took enormous risks-sometimes without seeming even to be aware of them. Among the reasons why Paine is a figure of enduring fascination is that he defies easy classification as a thinker or as a human being.

Paine was, first and always, an intellectual. Today he would be called a public intellectual. Among other things, this means that he was no politician. 
This is not to deny that Paine sought-and achieved-remarkable political influence. Common Sense is widely credited for galvanizing disaffected American colonists to demand independence from Britain. His Crisis letters garnered comparable acclaim for sustaining American forces through the darkest days of the Revolutionary War-when defeat seemed all but inevitable. The Declaration of Independence mimics Paine's style and arguments so thoroughly that some claimed him as its ghost author-even though Paine denied this. ${ }^{12}$ The rousing effects of his Rights of Man on Britain's lower orders were sufficiently alarming to elites that the government poured great effort into discrediting him and, when that failed, into prosecuting him. In France he served as one of nine deputies on the committee that drafted the post-Revolution constitution (and one of only three who survived the Reign of Terror), and he supplied Napoleon with plans for a proposed invasion of Britain along the Lincolnshire coast-whose contours he knew well from his years as an excise man. ${ }^{13}$ President Jefferson often sought his advice, most notably to resolve the crisis that led to the Louisiana Purchase in $1803-$ even if he was by then so great a liability that Jefferson would not acknowledge him publicly. ${ }^{14}$

Influence is one thing; politics, another. Paine wielded one of the most inspiring pens of the century, but this was not matched by a facility for persuasive public speaking. Few letters or other direct sources of evidence about his character have survived, yet it seems clear that, despite an arresting twinkle in his eyes, he was devoid of personal charisma. He could be engaging in conversation but was often withdrawn in company. Though tall and reputedly handsome, he had a bulbous nose that deteriorated with age, possibly due to chronic rosacea. This helped his enemies exaggerate his drinking, denigrating him as an alcoholic. ${ }^{15} \mathrm{He}$ had a searingly acute analytical intellect, but he always wrote from the heart with uncompromising passion-scorning those who pulled punches or sought the middle ground. He heaped vitriol on his critics, particularly if they had once been friends. Rights of Man was at least as famous for its contemptuous derision of Burke as for the substance of Paine's arguments. George Washington, who had helped him greatly as a young man and whose prowess as a general he had defended against critics during the war, would eventually be trashed by Paine not only as an incompetent soldier who had been bailed out by the French, but as "treacherous in private friendship" and so hypocritical that "the world will be puzzled to decide whether you are an apostate or an imposter." 16 Paine's ravenous need always to have the last word, as in the escalating venom that marked his replies to critics of The Age of 
Reason, meant that even the like-minded would often sidestep association with him.

Common Sense was well crafted to win support for Paine's revolutionary cause, but in this it was exceptional. For the most part he was clueless about how to build political coalitions, when to keep his powder dry, or even why it might sometimes be wise to avoid giving unnecessary offense. As a result, most of his direct interventions in politics were disastrous flops. His petition to Parliament on behalf of the excise collectors achieved nothing but his firing. His service to the American Revolution should have secured him lifetime positions of honor and financial security in the new order, but he seldom held on to appointments for long, and political adversaries easily ran rings round him. Even when Paine was in the right (as in his accusations that Silas Deane had been an opportunistic traitor who secretly worked for the British during the war), Paine managed to come off as the political loser. His revolutionary credentials secured him French citizenship and invitations to represent no fewer than four constituencies at the National Convention in 1792 (he opted for Calais), but his censorious style soon alienated potential allies. His speech to save Louis XVI's life the following January was a noble gambit, but it fell on deaf ears and predictably finished Paine as a significant figure at the convention. By the time Maximilien de Robespierre and Jean-Paul Marat turned on him, driving him first from the convention, then from French public life, and finally into prison, no one who could help him was willing to take up his cause. That he avoided the guillotine seems to have been due mainly to the incompetence of his captors.

Nor was Paine a scholar. He was voraciously curious and widely readimpressively so by any measure but especially given his lack of formal education. Like the other American founders, he wrote in conversation with major thinkers from the past, but he absorbed ideas from them and those around him more like a sponge than a student or a participant in disciplined intellectual exchange. He seldom rewrote or even revised his work, which was uncluttered by references and other scholarly paraphernalia. No doubt this contributed to its accessibility. He scoffed at the suggestion that his ideas were derived from John Locke, whom he dismissed as too speculative and impractical to be worth his time. ${ }^{17} \mathrm{He}$ blended the analytical and the polemical in ways that are reminiscent of Jean-Jacques Rousseau and Karl Marx. For Paine, ideas were rocks to be hurled at adversaries and to provide the motivating foundations for political action. He had an unerring faith in the power of reason to move people, which meant that he had more 
in common with the European rationalist tradition, from René Descartes to Immanuel Kant, than with the British empiricists, from Thomas Hobbes to David Hume, for whom reason is, as Hume put it, the slave of the passions. ${ }^{18}$ But Paine's rationalism was for Everyman. ${ }^{19}$ As R. B. Bernstein puts it, Paine democratized political language, transforming it "from a medium restricted to the intellectual elite" into a medium that "any intelligent person could use." 20 It was not the prerogative of political elites "to begin the world over again," as Paine declared in the conclusion to Common Sense. ${ }^{21} \mathrm{He}$ saw mankind through the lens of his own bootstrapped biography, convinced that vivid depictions of people's interests and the ways in which they were frustrated by corrupt and exploitative arrangements would move people to tear down the instruments of their oppression.

This is what made him dangerous. Craig Nelson points out that what distinguished the second part of Rights of Man, published in I792, from the first (I79I)-and moved the attorney general to prosecute Paine-was not its message but its likely audience. Part the Second immediately became widely and cheaply available, spurring fears that it would be the kind of catalyst to rebellion in England that Common Sense had been in America. ${ }^{22}$ Likewise, Nelson observes that The Age of Reason provoked fury among American elites, who often did not dispute Paine's deist message but opposed sharing it with the middle and lower classes, which were Paine's natural audience. The worry was what today might be called a Straussian anxiety, that if their children "were not Sunday schooled in notions of good and evil, of striving for the rewards of heaven and fearing the punishments of hell, they would become as immoral as apes." ${ }^{23}$ Paine was a true believer in the rational capacities of the common man. His vocation was to excite them to action which would be unmediated by self-appointed guardians of prudent political evolution. This is why his work has always appealed to intellectual activists. Paine was anti-elitist to the core.

Paine's anti-elitism colored his enthusiasm for the scientific revolution that accelerated around him over the course of his life. His relentless curiosity bespoke a Renaissance intellect, fueled, no doubt, by his association with such brilliant figures as Franklin, Washington, Jefferson, Antoine-Nicolas de Caritat (Condorcet), Mary Wollstonecraft, Benjamin Rush, William Blake, Richard Price, and William Godwin. Whether he was trying to account for the origins of flammable methane, building a pierless bridge that could span freezing rivers (a lifelong obsession at which he eventually succeeded), or opining about the need for independent banks and international political institutions, Paine exuded confidence that every facet of nature and every human contrivance could be thoroughly under- 
stood and tamed for benevolent ends. Yet he was not in the least drawn to the kinds of technocratic elitism or vanguardism that would-in different ways-appeal to Enlightenment thinkers like Jeremy Bentham and Karl Marx. He also had no time for the neo-Aristotelian political science of institutional design, based on metaphors - if not theories - of balance, separation, and equilibrium, which motivated others in America's founding generation. ${ }^{24}$ Paine was a pragmatist about institutions, and his views about them evolved with his experience. His strongly egalitarian instincts, combined with his contempt for European monarchs - dead and living-many of whom struck him as little better than imbeciles, inclined him initially to bet on strong democracy expressed through unfettered unicameral legislatures. But he eventually changed his mind. In I 786 he attacked the Pennsylvania legislature's revocation to the Bank of North America's charter (the bank had opposed the government's inflationary printing of money), during the course of which he endorsed bicameralism and robust courts as checks on "the despotism of numbers." ${ }^{25}$ No doubt his subsequent experience at the hands of the French National Convention reinforced his worries about majoritarianism.

Part of the reason that Paine did not reify particular political arrangements is that he did not harbor an elevated view of politics. To be sure, he believed that government had a major role to play in preventing domination and redistributing wealth. The second part of Rights of Man argued for progressive taxation to fund the rudiments of a welfare state. Agrarian Justice, composed in 1795 and 1796 , called for estate taxes to reduce inequality by providing substantial payments to young adults and lifetime pensions for the elderly. These attacks on the privileges of property engendered predictable excoriation, particularly from those who identified the ownership of property as a natural right or a precursor for citizenship. Paine's arguments in these works have often led progressives to portray him as a kind of proto-socialist. The shoe does not fit, partly, as Nelson notes, because Paine was an admirer of Adam Smith's arguments in support of commerce and market economics. ${ }^{26}$ But the shoe is also a bad fit because Paine had a strong anti-statist streak. Although he declared at the outset of Common Sense that "society in every state is a blessing," he was adamant that "government even in its best state is but a necessary evil." Typically, it is no better than a monument to the human propensity for sin. Government "is the badge of lost innocence." 27 In what might have been James Madison's inspiration for Federalist No. 5I, Paine lamented that if only "the impulses of conscience" were "clear, uniform, and irresistibly obeyed, man would need no other lawgiver." ${ }^{28}$ As it is, our propensity to do evil to one another 
makes government essential. Lacking the lofty view of government and politics that so often accompanies socialist worldviews, Paine would not have lost much sleep over changing his mind about particular institutional arrangements in light of his experience.

At times such changes of mind enabled Paine's enemies to dismiss him as an opportunist. It is true that he was not above taking polemical stands that contradicted his professed beliefs and commitments, as Jane Calvert details in her contribution to the present volume with respect to his dealings with the Pennsylvania Quakers. But it would be difficult to pin opportunism on Paine as a general or summary charge of flawed character. For one thing, he held steadfast to core moral convictions throughout his life: on the existence of a supreme being, on the injustice of slavery, and on the wrongness of the death penalty. Moreover, he stuck to these convictions through thick and thin-even, as we saw with his deism and his effort to save Louis XVI- when this threatened his own livelihood or indeed his life. It is hard to imagine Paine dismissing consistency as the hobgoblin of little minds; his faith in reason was too powerful for that. By the same token, however, he was reluctant to reify political tactics, strategies, or institutions. Paine was a man of action who recalibrated many of his beliefs in light of his experience and changing circumstances, but he did not want for a moral compass. Indeed, one reason for his defense of deism in The Age of Reason was his conviction that without it there would be no anchor for moral imperatives geared toward the possibility of human improvement. It seems that he anticipated-and feared-the nihilist conclusion that if there is no god, then anything is permitted..$^{29}$ Mere humanism, for Paine, was not enough.

Joyce Appleby notes that Paine was not an especially profound thinker and that his political theorizing could sometimes be rambling. ${ }^{30}$ But there is, nonetheless, an arresting quality to his best writing that stemmed from his impulse to drive ideas to the hilt: to defend them without qualification and to take them to extremes that would not occur to others-let alone garner their endorsement. In this -if nothing other than the bizarre subsequent histories of their physical remains - he is reminiscent of Jeremy Bentham. ${ }^{31}$ Appleby describes Paine as "a vector for the radical theorizing about the origins of government" begun by Hobbes and Locke in the seventeenth century; modified by such eighteenth-century anti-absolutists as Montesquieu, Voltaire, and Rousseau; and repatriated to England as Paine was finding his intellectual feet; that he soaked up these ideas along with the other anti-elitist currents that were swirling around him; mixed them "with 
his rage at the way English institutions thwarted the ambitions of ordinary men, and discovered in the American struggle "the cause of all mankind." 32 To this it should be added that just as he pushed common complaints about Britain's overbearing colonial administration into a full-throated roar for American independence in Common Sense, so he revamped contractual understanding of the relations between the people and their governments into a relentless denunciation of every last vestige of monarchical or aristocratic authority in his Rights of Man.

Though Paine was not a profound theoretician, there are two ways in which he was strikingly novel. One is that his underlying disposition was democratic to the core. Paine did not actually say that much about democracy. The term does not even appear in Common Sense, which, judging from his choice of epitaph, he regarded as his greatest work. ${ }^{33}$ Nor is democracy a major motif in Rights of Man, though his assumptions and assertions about it in the book are revealing. In the course of heaping scorn on Burke's reverence for aristocrats, whom Paine dismisses as little more than inbred degenerates, he insists that "the greatest characters the world have known, have rose on the democratic floor." ${ }^{34}$ Just as Paine never doubted his own understanding or capabilities, he saw no reason that others should prostrate themselves before those who had arbitrarily been privileged by birth. This illuminates what might otherwise seem like an odd mixture of arrogance and humility: he was conceited in that he saw no reason ever to defer to anyone because of wealth, status, or rank; but he was humble in that he never expected deference from anyone else. The core of his disposition was egalitarian, reflected, as I noted earlier, in his appeal to unadorned reason. To be sure, people sometimes disappointed him-as when Congress denied him a pension. But this was about what he perceived as ingratitude for his service to the nation, not a failure to acknowledge his importance.

That heredity could be the source of anything valuable in politics struck Paine as ludicrous. He thought the notion of a hereditary legislator "as absurd as an hereditary mathematician, or an hereditary wise man; and as ridiculous as an hereditary poet-laureat." ${ }^{35}$ The natural thing is for people to govern themselves. Thus while most ancient governments "present to us a miserable picture of the condition of man," Athens was the exception. "We see more to admire, and less to condemn, in that great, extraordinary people, than in any thing which history affords." Paine speculated that had Athens not been small enough for the people to govern themselves directly, the Athenians might have come up with the idea of representative government as the natural response to the challenges of scale, saving mankind 
from centuries of grief. Had that occurred, there is no reason to suppose that monarchy or aristocracy, "those unnatural modes of government," would ever have been instituted. ${ }^{36}$

Paine's enthusiasm for Athenian democracy gives him the rare distinction of being one of democracy's earliest modern supporters. The democratic idea was not, of course, new in the eighteenth century, but it had few categorical defenders. In this, it was distinctive. The other major political ideologies of the Enlightenment have been made famous by their champions. Hobbes and Locke were advocates for the social contract. Jeremy Bentham and John Stuart Mill were the animated architects of utilitarianism. Karl Marx and Friedrich Engels were communism's apostles. Democracy, by contrast, had for centuries been made famous by its critics - the most famous of whom had been Plato and Aristotle. The American founders were keenly aware of their antipathy for the Athenian model, which they blamed for the mob mentality that had led to the death of Socrates. This was partly why the founding generation saw their enterprise as a neo-Roman venture to create what Madison would describe in Federalist No. IO as a nontyrannical republic as distinct from a "pure democracy." And it is why the founders drew on Aristotle's mix of the one, the few, and the many, rather than any variant of the Athenian model. Paine had no time for the one or the few, as we have seen. For him, the great modern invention was representative government. It was sufficient to address the challenges of size, adapting the Athenian ideal to the modern world.

As this last observation suggests, Paine was a novel thinker also in that his central preoccupations were remarkably prescient. He was one of the very first to realize, more than four decades before Alexis de Tocqueville wrote Democracy in America, that in the big sweep of history, monarchy and aristocracy were finished as sources of political legitimacy. ${ }^{37}$ In the future, legitimacy would flow from the people. He was more confident than the other American founders (with the possible exception of Madison toward the end of his life) that majoritarian politics had arrived to stay and that it must ultimately constrain republican institutions ${ }^{38} \mathrm{He}$ saw that, despite its limitations - and he was keenly aware of at least some of them-representative government would have to be the engine by which the moral authority of democracy was reconciled with realities of modern mass politics. John Stuart Mill would take up the subject in definitive detail seven decades after the appearance of Rights of Man, but in a noteworthy sense, Paine set the table for Mill's discussion. ${ }^{39}$

Paine's writings about taxation, redistribution, and pensions were also remarkably forward-looking. As I noted earlier, they prefigured debates 
about the twentieth-century welfare state long before anything resembling modern nation states were even dimly in view. Paine's populist inclinations notwithstanding, he also exhibited a surprisingly sophisticated grasp of markets, banking, and public finance-including at least some of the institutions they were going to require. And, more than half a century before nationalism would begin sweeping the world in ways that would transpose commerce and international conflict into new keys, Paine was thinking about the need for international institutions based on a global convention of delegates, along the lines of the United Nations. ${ }^{40} \mathrm{He}$ insisted against Abbé Guillaume-Thomas Raynal that all countries, whatever their internal political forms, "are relatively republics with each other," and that there should be international agreements limiting the size of navies to ensure the "future tranquillity of mankind"-a precursor to modern arms-reduction agreements. ${ }^{41}$

In short, as Jonathan Clark notes in his essay in this volume, Paine defies attempts to slot him into the usual pigeonholes. This partly accounts for why, just as many have found things to despise in his writings, a remarkably diverse assemblage of successors has subsequently claimed Paine's mantle. For Philip Foner and Harvey Kaye, he was a kind of proto-Marxist whose ideas have inspired socialist and working-class movements since the eighteenth century. ${ }^{42}$ Teddy Roosevelt's antipathy notwithstanding, Paine was indeed a stalwart of the progressive movement. Yet, as J. G. A. Pocock has noted, Paine never fit neatly into the mold of radical politics ${ }^{43}$ His libertarian streak has also appealed to iconoclastic anti-statists like Christopher Hitchens. ${ }^{44}$ Paine has been embraced by conservatives like Ronald Reagan, who turned to him for the proposition that "we have it in our power to begin the world over again" in accepting his party's presidential nomination in I980, not to mention Glenn Beck - who surely deserves an Olympic gold medal in chutzpah for declaring Paine to be "the me of his generation." 45 Romantic nationalists like Walt Whitman credited Paine with substantial responsibility for America's independence, for "severing the nation from ecclesiastical and superstitious domination," and embracing a constitution that incorporates a "radical" respect for human rights. ${ }^{46}$ But Paine has appealed to writers and poets of many stripes, including Ralph Waldo Emerson, Henry David Thoreau, Theodore Parker, Samuel Clemens (Mark Twain), and Herman Melville. ${ }^{47}$ In I925 Thomas Edison declared Paine to be "our greatest political thinker" whose "sagacious reasoning" was "surpassed nowhere else in American letters" and "seldom in any school of writing." 48

Militarists have also found alluring strands in his writings. General George Patton turned to the opening paragraph of Paine's first Crisis 
pamphlet to rally European troops against Hitler, declaring that "tyranny, like hell, is not easily conquered." 49 David Frum and Richard Perle began their neo-conservative tract on counterterrorism after the September I I, 200I, attacks with "These are the times that try men's souls"-the oft-repeated line also deployed by FDR following the Japanese attack on Pearl Harbor..$^{50}$ Not to be forgotten, on the topic of trying times, is Barack Obama's first inaugural declaration in January of 2009 at the height of the global financial crisis, that future generations would learn that "in the depth of winter, when nothing but hope and virtue could survive ... the city and the country, alarmed at one common danger, came forth to meet it." ${ }^{51}$

It is true that the aphoristic character of many of Paine's writings makes them readily available to people of many stripes. When Frum and Perle took aim at "the summer soldier and the sunshine patriot" who "will, in this crisis, shrink from the service of his country," they no doubt had rather different people in mind from those Paine was thinking about when he crafted his first Crisis pamphlet in December of I776-not to mention the scores of people who have called on these words in multiple settings in the years since. And while Paine's enthusiasm for America has often garnered the attention of romantic nationalists, we should not lose sight of the reality that this self-described citizen of the world saw the human condition in unremittingly cosmopolitan terms. "The cause of America is in a great measure the cause of all mankind" he declared in Common Sense, ${ }^{52}$ a view Lincoln would repeatedly echo eight decades later in his universalist depictions of the Union cause in the Civil War. ${ }^{53}$

Paine bet on America as the harbinger of democratic change throughout the world, as he would later bet on France, though both would subsequently disappoint him. In this he is reminiscent of Alexis de Tocqueville, who also thought American democracy a model for France and would also be doubly disappointed-if for illuminatingly different reasons. Whereas Paine hoped America would be an exporter of leveling egalitarianism, for Tocqueville it offered the best model of how to domesticate that ideology via republican practices and institutions. The French inability to heed what Tocqueville took to be America's lessons had played itself out not only after I 789 but also in the revolutions of 1830 and, as he would remind readers in the preface to the twelfth edition of Democracy in America, in I848. ${ }^{54}$ Tocqueville would eventually despair of the American experiment. He lost his earlier confidence that American individualism could be inhibited by "selfinterest rightly understood" or sequestered from politics, which struck him as increasingly dominated by people lacking in "moderation, sometimes probity, above all education." ${ }^{55} \mathrm{He}$ had always been troubled by American 
slavery, but when he wrote Democracy in America, he thought it was dying out. ${ }^{56}$ With the passage of the Kansas-Nebraska Act in I854, the election of James Buchanan two years later, and the Dred Scott decision and the dress-rehearsal for the Civil War in Kansas prompted by the adoption of a pro-slavery constitution there the year after that, Tocqueville decided that he had also been wrong about slavery and that its looming expansion into the territories would destroy what remained of America's decaying moral authority in Europe.$^{57} \mathrm{He}$ never lived to see the Civil War erupt, but the distress manifest in his last letters to American friends suggests that he would not have been surprised. ${ }^{58}$

By the time the war arrived, Paine had been dead for half a century. America was on its sixteenth president, the man who had been an infant in rural Kentucky when Paine died and who would come eventually to admire Paine's theology and imitate his rhetorical style. But what would Paine have made of Lincoln? Surely he would have admired Lincoln after January of I 863. The Emancipation Proclamation would have resonated with Paine's antipathy for slavery, as would the theological reticence that infused Lincoln's second inaugural address. ${ }^{59}$ But it is hard to imagine Paine embracing Lincoln's earlier political stance. The I860 Republican platform, famously set forth in Lincoln's Cooper Union speech and reiterated in his first inaugural address, opposed extending slavery into the territories but accepted it in the South. In effect, Lincoln sought to reinstate the status-quo ante that had collapsed when the Kansas-Nebraska Act upended the Missouri Compromise of $1820 .{ }^{60} \mathrm{It}$ is difficult to see Paine endorsing Lincoln's pragmatic willingness to accept Southern slavery in hopes of saving the Union. Had he been willing to join the party at all, he would likely have sided with more-radical Republicans who wanted emancipation as a war aim from the start. For the same reason, he would have looked askance at Lincoln's preliminary Emancipation Proclamation of September I862, which threatened emancipation of slaves only in rebel states that did not return to the Union by the year's end. ${ }^{61}$

Paine would likely have resisted Lincoln's underlying logic that, in order for American democracy to be a beacon to the world, preserving the Union was more important than abolishing slavery right away. ${ }^{62}$ That view might have been tenable in the late eighteenth century, perhaps as late as the end of the Napoleonic Wars. ${ }^{63}$ Indeed, the fact that Paine never attacked the compromises with slavery built into the Constitution might be invoked as ballast for the suggestion that it might have been his view-even though Paine never explicitly said so. Moreover, it now seems unlikely that Paine wrote "African Slavery in America," published in The Pennsylvania Journal; and Weekly Advertiser in March of 1775 and often attributed to 
him, and it is certain that his participation in anti-slavery societies has been exaggerated. ${ }^{64}$

But the world was a very different place by i860. The Atlantic slave trade had been illegal for more than half a century-stamped out by the British navy everywhere except Cuba, where it would end in a few years. Slavery itself had been illegal throughout the great bulk of the British Empire for nearly three decades. ${ }^{65}$ Surely someone with Paine's sensibilities would by then have shared the lens through which the aging Tocqueville had come to view slavery as the defining moral issue of the age-and Paine would probably have rendered a verdict similar to Tocqueville's. After all, even James Lynch, who has set the record straight concerning the exaggeration of Paine's role as an abolitionist, concludes that perhaps no one hated "the concept" of slavery more than Paine did; that he "found it repulsive and sincerely hoped for its eradication"; that he warned Jefferson of the "immorality" of extending slavery into Louisiana; and that in I79I he described the Haitian Revolution in Saint-Dominique as the "natural consequence of slavery." ${ }^{66}$ It is hard to imagine someone with these sentiments dragging his feet over the slavery issue by $\mathrm{I} 860$.

Some of Lincoln's other compromises, in particular his willingness to compensate slave states for emancipation along the lines that the British had pursued in the West Indies, might have appealed to Paine more. ${ }^{67}$ Paine was no pacifist. He thought that war is at times necessary and indeed desirable in pursuit of a righteous cause; this belief lay at the heart of his differences with the Pennsylvania Quakers explored by Jane Calvert in this volume. Nor was Paine merely a humanist, as I have noted; but he was a humanist. He valued life and disliked gratuitous killing. His manifest idealism notwithstanding, he was not above tactical or strategic compromise to vindicate his ideals - even if he sometimes lacked the judgment to know which compromises would likely be effective. Nor did Paine think money or property sacrosanct; he often forwent royalties to promote the diffusion of his ideas, and he gave away most of his assets to support the army during the Revolutionary War. Had the South been willing to buckle, for a price, as Lincoln hoped they would in I862, Paine might have agreed with him that it was worth it to the Union to end the war. Indeed, when Lincoln returned to the issue of compensation in the war's waning days, to stop what had become senseless killing by any measure now that the outcome was beyond all doubt, he might well have received a more indulgent hearing from Paine than he did from his cabinet colleagues. ${ }^{68}$

If Paine's beliefs defy easy classification, so does his personality. This is partly due to the dearth of direct evidence about his personal life, al- 
ready mentioned. Nelson, among others, speculates that he might have been something of a manic-depressive ${ }^{69}$ Paine's intense confidence, not to say obsessive single-mindedness, together with a disregard for his personal and financial security, which many would judge reckless, might arguably be evidence of manic "highs." But his bouts of depression were situational, not endogenous. There were good reasons for them: personal losses and betrayals, the failure of professional and political projects, and physical illness and decline. ${ }^{70}$ Indeed, what is remarkable about Paine is how frequently he triumphed over adversities that would have overwhelmed most people. Still, to classify Paine merely as a conventional-if tough, resourceful, and intense-personality, would miss important dimensions of his temperament. His extreme literal-mindedness and rigidness in the face of criticism, together with his imperviousness to how others saw him, suggest that in some fundamental way he was a loner.

The fact that Paine had virtually no personal emotional life, so far as anyone has been able to discover, after the death of his first wife in 1760 (when he was twenty-four years old) lends credence to this suspicion. Keane notes that there is serious doubt as to whether Paine's second marriage was ever consummated. Certainly he and Elizabeth Ollive spent virtually no time together even before their separation, and he was uncharacteristically evasive and defensive when asked about it. ${ }^{71}$ Eileen Hunt Botting notes in her contribution to the present volume that enemies like George Chalmers and James Cheetham accused Paine of fathering an illegitimate child during an affair he was alleged to have engaged in with Marguerite de Bonneville. They also accused him of worse, but though the charges remained in currency, sullying Paine's name for many decades after his death, none of them withstands scrutiny. ${ }^{72}$ And although contemporaries sometimes commented on the dearth of Paine's interest in women and his preference for male company, no one has adduced evidence that he had homosexual inclinations-or, at any rate, that he acted on them, if he did. Paine seems, rather, to have been someone who was uncomfortable with close personal connection. Certainly his brief experience of marriage did not endear him to the institution, which he dismissed as enervating in one of his few pronouncements on the subject. ${ }^{73} \mathrm{He}$ seems to have been free of the loneliness that often drives people into unsatisfactory relationships when satisfying ones are unavailable, preferring solitude and platonic friendships to the rewards, risks, and demands of human intimacy.

Paine's lack of deep human connection might have been reinforced by the fact that his sense of belonging was so often compromised. He must have felt like an interloper among the richer children in the local Thetford 
Grammar School, and as a young man when he muscled his way into London's elite intellectual circles. He can scarcely have known America when Common Sense catapulted him to prominence little more than a year after his arrival there; for most people it would have been a surreal experience. He was feted as a national hero after the Revolutionary War, and later he would receive a hero's welcome in France after what would turn out to be his permanent exile from Britain in I792. But neither of his adopted homes would be sanctuaries, at least not unambiguous ones. His French citizenship and status as a National Convention deputy could not save him from the Luxembourg Prison at the height of the Terror in late I793. ${ }^{74}$ They did, however, enable his sometime antagonist Gouverneur Morris (then George Washington's minister plenipotentiary to France) to declare that Paine had forfeited his American citizenship and let him languish in prison without diplomatic help for months - severely ill with typhus and under perpetual threat of execution. And when he finally returned to America in I802, Paine found that the reaction to The Age of Reason was decidedly bimodal. It had its voluble admirers, but he was also viciously attacked by the religious establishment and relentlessly pilloried in the press as a debauched and traitorous malcontent. He was summarily ostracized by longtime friends, including Benjamin Rush, Patrick Henry, John Jay, and, perhaps most painfully of all, his old revolutionary ally Samuel Adams. ${ }^{75}$ It is likely that Paine never felt fully at home anywhere, and notable that one of his biographers identified him as history's greatest exile. $^{76}$

Part of the enduring fascination with Paine is that he is enigmatic and difficult to peg, both as a historical figure and as a human being. To some extent this has been aggravated by distortions promoted or tolerated by his enemies, not a few of whom wielded considerable influence and power. Some, like John Adams, were jealous of his skills and success as a writer. Others, like Robert Aitken, James Cheetham, and William Carver, harbored resentments borne of personal conflicts - often over money, recognition, or both. His political intemperance antagonized people like John Jay, Samuel Adams, Gouverneur Morris, and George Washington. His visceral antipathy for deference combined with his impulse to speak directly to the common man infuriated establishment figures. Nowhere was this more manifest than with Paine's deism, which stood as an unvarnished rebuke to people and institutions whose legitimacy depended on claiming knowledge of God's word and access to the Divine plan. ${ }^{77}$ If Paine was right, they were nothing better than deluded fools or charlatans-and he never tired of saying so. Many people who talked about democracy had no interest in 
practicing it as thoroughly and as personally as Paine insisted on doing. For this, he paid a significant price.

If Paine's detractors had the upper hand when he died, and retained it for generations due to slanderous biographies commissioned or written by his enemies, it does seem that a more-measured and accurate picture of him and his ideas has triumphed over the past half century. Biographers, notably Keane and Nelson, have successfully scotched the worst calumnies. ${ }^{78}$ Monuments, libraries, and societies have immortalized his contributions on both sides of the Atlantic. American presidents of every ideological stripe now reach for his name in times of crisis, underscoring his normalization as one of the nation's inspirational architects. To some extent this has been helped along, as Kaye notes, by the de-idealization of America's other founding fathers-as historians have discovered and written more about their flaws and limitations. ${ }^{79}$ Whatever the reason, Paine has taken his rightful place in the American historical pantheon. He will never be recognized in the same way as Washington, Madison, Jefferson, or Jay, because he never held major political office in the United States. Indeed, the only political office of any consequence that he ever held was his improbable stint as the deputy for Calais to the French National Convention in I792-I793, where he could not even speak the language in which business was being transacted. But as a political thinker and public intellectual, he was every bit their equal, and in some ways he bettered them.

Some will, perhaps, contest that judgment; but what is beyond debate is that Paine was one of modern democracy's earliest and most articulate champions. His democratic commitments shaped his personal dealings as much as his views of politics; indeed the two flowed into and reinforced one another. Paine despised pomposity and pretense as much as he did domination and arbitrary power, skewering both-often in the same paragraph-with the withering contempt that flowed so effortlessly from his pen. This bought him enemies and cost him recognition. But for all his prickliness and pride, Paine's writings and actions radiated a commitment to a democratic cause that he never doubted was larger than himself. $\mathrm{He}$ worked for it, fought for it, and, on more than one occasion, showed himself willing to die for it. That is the essence of his legacy, and it is the chief reason he commands enduring respect.

I. Roy P. Basler, ed. Abraham Lincoln: His Speeches and Writings (Cleveland and New York: World Publishing, 1946), p. 6. 
2. Michael Burlingame, Abraham Lincoln: A Life, 2 vols. (Baltimore, MD: Johns Hopkins University Press, 2008), vol. 2, p 83.

3. Theodore Roosevelt, Gouverneur Morris (Boston: Houghton Mifflin, I898), p. 289.

4. Darwin continued: "Remember that an enemy might ask who is this man ... that he should give to the world his opinions on the deepest subjects? . . . but my advice is to pause, pause, pause." "Darwin C. R. to Darwin G. H.," Letter 9I05, October 2I, I873, Darwin Correspondence Project, http://www.darwinproject .ac.uk/letter/entry-9I05 [accessed oI-09-20I4].

5. John Keane, Tom Paine: A Political Life (New York: Grove Press, I995), p. ix.

6. David Chen, "Rehabilitating Thomas Paine, Bit by Bony Bit," The New York Times, March 30, 200I, http://www.nytimes.com/200I/03/30/nyregion/ rehabilitating-thomas-paine-bit-by-bony-bit.html [accessed 6-I I-20I 2]. "Thomas Paine's Remains Are Still a Bone of Contention," http://articles.latimes.com/200 I/ apr/or/news/mn-4543 I [accessed o I-I6-20 I4]. See also Paul Collins, The Trouble with Tom: The Strange Afterlife and Times of Thomas Paine (New York: Bloomsbury, 2005).

7. Craig Nelson, Thomas Paine: Enlightenment, Revolution, and the Birth of Modern Nations (New York: Penguin, 2006), pp. I2-50.

8. The Crisis (also known as The American Crisis) eventually appeared as a series of sixteen pamphlets, the first thirteen published between 1776 and I777, and the last three between $\mathrm{I} 777$ and I783.

9. Paine, The Crisis, "Number I," this volume, p. 58.

Io. See, for example, Bruce Ackerman and Anne Alstott, The Stakeholder Society (New Haven, CT: Yale University Press, 2000), who turn to Paine's argument in Agrarian Justice as inspiration for their proposal that eighteen-year-old high school graduates should receive an $\$ 80,000$ stake from the state, funded by a 2 percent annual wealth tax on households with assets in excess of \$I.5 million. Paine's variant had called for a £I5 stake to be given every twenty-one-yearold, paid for by a Io percent estate tax on inheritances passed to close relatives (and somewhat higher rate on other bequests), which would also fund a pension scheme for the elderly and disabled.

I I. Nelson, Thomas Paine, pp. 60-62.

I2. Keane, Tom Paine, pp. I35-I37.

I3. Nelson, Thomas Paine, pp. 38-39, 298-304.

I4. Keane, Tom Paine, pp. 472-482.

I5. Nelson, Thomas Paine, pp. 20-2 I, 327.

I6. Ibid., pp. 292-294.

I7. Ibid., p. 320. 
I 8. David Hume, A Treatise of Human Nature, bk. II, pt. III, § 3 (Oxford, UK: Clarendon, I896 [I739]), p. 4I5.

I9. See Eric Foner, Tom Paine and Revolutionary America (New York: Oxford University Press, 2005), pp. 7 I-I06.

20. R. B. Bernstein, "Rediscovering Thomas Paine," New York Law School Law Review 39 (I994), p. 9I9.

2 I. Paine, Common Sense, this volume, p. 46.

22. Nelson, Thomas Paine, p. 227.

23. Ibid., pp. 265-266. The twentieth-century political theorist Leo Strauss believed that the esoteric knowledge that we know nothing was too dangerous to be put into common political currency, so it had to be hidden in philosophical nuance that was accessible only to the cognoscenti. For the masses, a more-benign exoteric message was in order, designed to ensure that they would not upset the political order that made life safe for the intellectual elite. See Leo Strauss, "Persecution and the Art of Writing," in Strauss, Persecution and the Art of Writing and other Essays (Chicago: University of Chicago Press, I952), pp. 22-37; "On a Forgotten Kind of Writing," in Strauss, What Is Political Philosophy? and Other Studies (Chicago: University of Chicago Press, I959), pp. 22 I-232; and Strauss, "Exoteric Teaching," in The Rebirth of Classical Rationalism: Essays and Lectures by Leo Strauss, ed. Thomas Pangle (Chicago: University of Chicago Press, I989), pp. 63-7I. See also Laurence Lampert, "Strauss's Recovery of Esotericism," in Steven B. Smith, The Cambridge Companion to Leo Strauss (Cambridge: Cambridge University Press, 2009), pp. 63-92.

24. Bernard Bailyn, The Ideological Origins of the American Revolution (Cambridge, MA: Harvard University Press, I992). See Gordon Wood, The Creation of the American Republic I776-I787 (Chapel Hill, NC: University of North Carolina Press, I998), and J. G. A. Pocock, The Machiavellian Moment: Florentine Political Thought and the Atlantic Republican Tradition (Princeton, NJ: Princeton University Press, I974), pp. 462-532.

25. Nelson, Thomas Paine, pp. I49, I70-I7I.

26. Ibid., p. 290.

27. Paine, Common Sense, this volume, p. 8.

28. Madison's formulation was "If men were angels, no government would be necessary. If angels were to govern men, neither external nor internal controls on government would be necessary." Alexander Hamilton, James Madison, and John Jay, The Federalist Papers, ed. Ian Shapiro (New Haven, CT: Yale University Press, 2009), No. 5I, p. 264.

29. The aphorism sometimes misattributed to Nietzsche, "If God does not exist, everything is permitted," occurs in Fyodor Dostoyevsky's The Brothers Karamazov. Nietzsche's formulation is "Nothing is true, everything is allowed." 
Fredrich Nietzsche, Genealogy of Morals (Mineola, NY: Dover Thrift, 2003), p. I09.

30. See Joyce Appleby, "Introduction," in Thomas Paine, Common Sense and Other Writings (New York: Barnes and Noble Classics, 2005), pp. xv-xxxviii.

3I. After Bentham's body had been dissected in a public anatomy lecture, as stipulated in his will, his remains were embalmed and donated to University College London-where they are on permanent display. However, the mummification of Bentham's head left it looking grotesque, so the display instead contains a wax replica into which some of Bentham's hair has been implanted. Because the real head was famously used in student pranks, it has now been locked away. See "Auto-Icon," The UCL Bentham Project, http://www.ucl.ac.uk/Bentham-Project/ who/autoicon [accessed 08-09-20I2]; C. F. R. Marmoy, "The 'Auto-Icon' of Jeremy Bentham at University College, London," UCL Bentham Project, http://web .archive.org/web/200702 I0065I36/http://www.ucl.ac.uk/Bentham-Project/info/ marmoy.htm [accessed 08-09-2012]. Ironically but not surprisingly, Bentham despised Paine. He dismissed the "rotten" Rights of Man on the grounds that "it is written on the wrong principle; it never so much as mentions the greatest happiness principle." The account is from a dinner with Bentham reported by George Wheatley in "Letters Written to My Sister during a Visit to Jeremy Bentham in the Beginning of the Year I850," pp. 5I-52. Unrecorded copy made available to me by Philip Schofield, director of the UCL Bentham Project, September 8,2012 .

32. Appleby, "Introduction," pp. xxi-xxii.

33. The tombstone reads "On this site was buried Thomas Paine, Author of Common Sense."

34. Paine, Rights of Man (first part), this volume, p. 2 I I.

35. Ibid. p. 2 I I.

36. Paine, Rights of Man, Part the Second, this volume, p. 283.

37. Tocqueville visited America with Gustave de Beaumont in mid-I83I, initially to study the prison system. They traveled widely over the ensuing nine months, during which time Tocqueville gathered the materials for his magnum opus Democracy in America, which would appear in two volumes published in I 835 and I 840 .

38. On the evolution of Madison's views about majority rule, see my introduction to The Federalist Papers (New Haven, CT: Yale University Press, 2009), pp. ix-xxii, and The Real World of Democratic Theory (Princeton, NJ: Princeton University Press, 20I I), pp. 68-7I.

39. Mill's Considerations on Representative Government was first published in $\mathrm{I} 86 \mathrm{I}$. 
40. Nelson, Thomas Paine, p. I6I.

4I. Paine, "Letter to the Abbé Raynal, on the Affairs of North America in which the Mistakes in the Abbé's Account of the Revolution of America are Corrected and Cleared Up," reprinted in Daniel Wheeler, ed., Life and Writings of Thomas Paine, History of Economic Thought Books, McMaster University Archive for the History of Economic Thought, vol. 8, no. paine I908g (I908), pp. 245, 28I, http://ideas.repec.org/h/hay/hetcha/paine I908-99.html [accessed 08-I6-2012].

42. Philip Foner, "Thomas Paine: World Citizen and Democrat," introduction to Philip Foner, ed., The Complete Writings of Thomas Paine, 2 vols. (New York: Citadel Press, 1945), vol. I, pp. ix-xlvi; Harvey Kaye, Thomas Paine and the Promise of America (New York: Hill and Wang, 2005).

43. J. G. A. Pocock, "The Varieties of Whiggism from Exclusion to Reform," reprinted in J. G. A. Pocock, Virtue, Commerce, and History (Cambridge: Cambridge University Press, I985), p. 276. Pocock points out that despite the hatred of English governing institutions that infuses Common Sense, "it does not consistently echo any established radical vocabulary; Paine had no real place in the club of Honest Whigs to which Franklin had introduced him in London, and his use of anti-Normanism to insist that Britain did not have a constitution but rather a tyranny does not permit us to think of him (as contemporaries might have) as a New Model soldier risen from the grave. Moreover, when the Revolutionary War was over Paine returned to live under 'the Royal brute of Great Britain' as if nothing much had happened, nor was he pursued by the authorities until the very different circumstances of I79I. One of the few practicing revolutionaries in English history, he performed no independent revolutionary action in England."

44. Christopher Hitchens, Thomas Paine's Rights of Man: A Biography (New York: Atlantic Monthly Press, 2006).

45. Ronald Reagan, Acceptance Speech at the I980 Republican National Convention, http://www.nationalcenter.org/ReaganConvention I980.html [accessed 08-03-20I2]; "Glenn Beck Calls Himself Thomas Paine," YouTube, http://www .youtube.com/watch?v=j5qEkWF7HBo [accessed 08-03-20I2].

46. Walt Whitman, "In Memory of Thomas Paine," in Walt Whitman, Prose Works (I 892), http://www.bartleby.com/229/I I 22.html [accessed I2-I8-20I3].

47. Michael A. Lawrence, Radicals in Their Own Time: Four Hundred Years of Struggle for Liberty and Equal Justice in America (Cambridge: Cambridge University Press, 20I I), p. I25.

48. Thomas Edison, "The Philosophy of Paine" (1925), The Campaign for Philosophical Freedom, http://www.cfpf.org.uk/articles/scientists/tp/edison-tp .html [accessed 02-02-2 I03]. 
49. Nelson, Thomas Paine, p. 335.

50. Lawrence, Radicals in Their Own Time, p. 334. David Frum and Richard Perle, An End to Evil: How to Win the War on Terror (New York: Random House, 2004), p. I. FDR drew on Thomas Paine (The Crisis) in the most difficult of times; the Roosevelt Institute online archive, http://www.rooseveltinstitute.org/new -roosevelt/fdr-drew-thomas-paine-most-difficult-times [accessed oI-09-20I4].

5I. Barack Obama's First Inaugural Address, Washington, D.C., (January 2I, 2009), transcript in The New York Times, http://www.nytimes.com/2009/o1/20/ us/politics/2otext-obama.html?src=tp\&pagewanted=all [accessed $08-\mathrm{I} 5-20 \mathrm{I} 2$ ]. This quote is also from The Crisis.

52. Paine, Common Sense, this volume, p. 7.

53. This was perhaps most poignant in Lincoln's annual message to Congress in I862: "We say we are for the Union. The world will not forget that we say this. We know how to save the Union. The world knows we do know how to save it. $\mathrm{We}$-even we here-hold the power, and bear the responsibility. In giving freedom to the slave, we assure freedom to the free-honorable alike in what we give, and what we preserve. We shall nobly save, or meanly lose, the last best hope of earth." Abraham Lincoln, "Annual Message to Congress -Concluding Remarks," December I, I862, http://showcase.netins.net/web/creative/lincoln/speeches/congress .htm [accessed 08-I7-2012].

54. "American institutions, which for France under the monarchy were simply a subject of curiosity, ought now [1848] to be studied by Republican France. . . . While all the nations of Europe have been ravaged by war or torn by civil strife, the American people alone in the civilized world have remained pacific. Almost the whole of Europe has been convulsed by revolutions; America has not even suffered from riots. Private property is better guaranteed there than in any other land on earth. Anarchy is as unknown as despotism.... Where else can we find greater cause of hope or more valuable lessons?" Alexis de Tocqueville, Author's Preface to the I2th ed. in Democracy in America, ed. J. P. Mayer (New York: Anchor Books, 1969), pp. xiii-xiv. For further discussion, see my Democratic Justice (New Haven, CT: Yale University Press, I 999 [1848]), pp. 238-240.

55. Alexis de Tocqueville, Oeuvres complètes VII: Correspondance étrangere d'Alexis de Tocqueville, ed. François Mélonio, Lisa Queffélec, and Anthony Pleasance (Paris: Gallimard, I986), p. 277.

56. Tocqueville, Democracy in America, pp. 340-363.

57. David Goldfield, America Aflame: How the Civil War Created a Nation (New York: Bloomsbury Press, 201 I), p. I56.

58. See Aurelian Craiutu and Jeremy Jennings, "The Third Democracy: Tocqueville's Views of America after I840," American Political Science Review 98, no. 3 (August, 2004), pp. 39I-404. 
59. Lincoln was criticized in the Northern press for demurring divine support for the Union cause, noting that both sides "read the same Bible and pray to the same God, and each invokes His aid against the other. It may seem strange that any men should dare to ask a just God's assistance in wringing their bread from the sweat of other men's faces, but let us judge not, that we be not judged. . . . The Almighty has His own purposes.” Abraham Lincoln, Second Inaugural Address, Washington, D.C., March 4, I865, http://www.bartleby.com/I24/pres32 .html [accessed 08-I 8-20I2].

6o. "I have no purpose, directly or indirectly, to interfere with the institution of slavery in the States where it exists." Abraham Lincoln, First Inaugural Address, March 4, I86I, http://www.bartleby.com/I24/pres3 I.html [accessed o8I8-20 I 2]. See also Goldfield, America Aflame, pp. I 58-I 79.

6I. Preliminary Emancipation Proclamation, September 22, I862, http://www .archives.gov/exhibits/american_originals_iv/sections/transcript_preliminary _emancipation.html [accessed o8-I3-2012]; Allan Nevins, Ordeal of the Union, vol. 6, War Becomes Revolution, I862-I863 (New York: Scribner's, I960), pp. 23I-245.

62. Lincoln believed that so long as slavery was restricted to the existing slave states and kept out of the territories, it would eventually die out. See Goldfield, America Aflame, pp. I58-204.

63. In this connection it is worth noting that by the time Tocqueville published the first volume of Democracy in America in I835, his was actually a contrarian voice in the French debate about America. Most commentators had by then shed their earlier enthusiasm for the new regime as a model for France, partly because of the persistence of American slavery when it was being abolished elsewhere. See Craiutu and Jennings, "The Third Democracy," pp. 393-394.

64. See James V. Lynch, “The Limits of Revolutionary Radicalism: Tom Paine and Slavery," The Pennsylvania Magazine of History and Biography I23, no. 3 (July I999), pp. I8I-I82, I83-I88. Lynch also notes (p. I83) that there is no evidence that Paine wrote the preamble to Pennsylvania's Emancipation Act, as is often supposed.

65. In I 833 the British Parliament abolished slavery throughout the empire except for Ceylon, St. Helena, and some territories possessed by the British East India Company. Slavery would not finally be abolished in Puerto Rico until I873, and it hung on in Brazil until I888.

66. Lynch, “The Limits of Revolutionary Radicalism,” pp. I88, I94, I79.

67. On the emancipation with compensation plans that Lincoln floated in the first half of I862, see Goldfield, America Aflame, p. 248. On the British $£ 20$, 000, 000 indemnity (a colossal sum when it was authorized as part of the Emancipation Act of I 833) to West Indian planters who would lose their slaves 
over the next seven years, see Chaim D. Kaufman and Robert A. Pape, "Explaining Costly International Moral Action," International Organization 53, no. 4 (Autumn I999), pp. 639, 657.

68. After Congress had passed the Thirteenth Amendment in January of I865, when Lincoln still expected the war (which was costing \$3 million a day) to continue for at least three months, he proposed offering the Southern states $\$ 400$ million in government bonds, half payable by April I if they had by then surrendered to the Union army, and the other half upon their ratification of the amendment. No Cabinet member supported the proposal. Goldfield, America Aflame, p. 253.

69. Nelson, Thomas Paine, p. I38.

70. See Keane, Tom Paine, pp. 21 5, 230, 373, 382, 524, 53 I.

7I. Keane, Tom Paine, pp. 5I-52; 77-78, 229.

72. See Nelson, Thomas Paine, pp. 326-330. Bonneville and her husband, Nicolas, were friends with whom Paine had lived for several years after his release from prison in Paris. Paine supported her and several of her children in America in his later years and named her family in his will (she and one of her sons were among the few mourners at his funeral), but there is no evidence of a romantic involvement between them.

73. See Nelson, Thomas Paine, pp. 46-47. Nelson notes that Paine did write a letter with a softer judgment about marriage to a newlywed friend in I879, noting wistfully that the possibility had passed him by when he had been consumed with politics and revolution.

74. Ironically he was imprisoned on the (groundless) accusation that he was a British spy.

75. Nelson, Thomas Paine, pp. 269-270.

76. See David Powell, Tom Paine: The Greatest Exile (London: Hutchinson, I985).

77. It especially stung Gouverneur Morris, who, rather than exert any effort to get Paine released from the Luxembourg Prison in I794, wrote Jefferson: “... Lest I should forget it, I must mention, that Thomas Paine is in prison, where he amuses himself with publishing a pamphlet against Jesus Christ." Gouverneur Morris letter to Thomas Jefferson, January 2 I, I 794, http://www.familytales.org/ dbDisplay.php?id=ltr_gom469o [accessed 02-02-2013].

78. The first sympathetic biography did not appear until more than eight decades after his death. Moncure D. Conway, The Life of Thomas Paine: With a History of His Literary, Political, and Religious Career in America, France, and England, 2 vols. (New York: G. P. Putnam's Sons, I892, I893).

79. Kaye, Thomas Paine and the Promise of America, pp. I I-I2. 